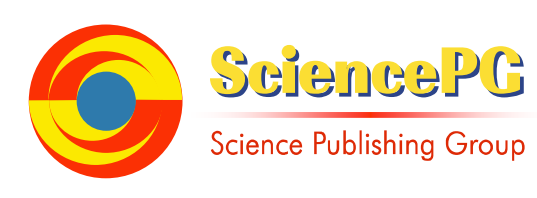

\title{
Fixing the content created in the act of knowing
}

\author{
Jesus Martinez del Castillo \\ Department of Philology, Faculty of Business Studies and Tourism, Universidad de Almería, Almería, Spain
}

Email address:

jesus.gerardo@ual.es, apofansis@msn.com

To cite this article:

Jesus Martinez del Castillo. Fixing the Content Created in the Act of Knowing. International Journal of Language and Linguistics. Special Issue: Linguistics of Saying. Vol. 3, No. 6-1, 2015, pp. 24-30. doi: 10.11648/j.ij1l.s.2015030601.14

\begin{abstract}
The human subject in as much as he knows transforms the sensitive and concrete (the thing perceived) into abstract (an image of the thing perceived), the abstract into an idea (imaginative representation of the thing abstracted), and ideas into contents of conscience (meanings). The last step in the creation of meanings, something being executed in the speech act, consists in fixing the construct mentally created thus making it objectified meanings in the conscience of speakers. The interchange amongst the different steps in the creation of meaning manifests lógos, the state lived by speakers in their interior when speaking, created and developed in words and because of words.
\end{abstract}

Keywords: Human Subject, Speaking, Saying and Knowing, Meaning, Thought, Logos, Human Knowledge, Sensation, Intellect, Imagination

\section{Introduction}

The act of knowing aims at transforming the initial intuition held by the speaking subject into contents of his conscience. Contents of conscience will eventually be changed into an act of saying and saying into words of a language. Because of this, words in themselves are virtual. They do not mean real things but classes of potential things, that is, categories. The purpose of language is re-structuring the things surrounding the speaking subject thus making them real. Once the classes of things are created it is necessary to fix them and orientate them to things in the world, thus making them words of a particular language and becoming the representation of real things.

\section{Giving the Construct a Name}

Under this heading I understand the intellective operation of giving a name to the mental construct created so far in the act of knowing, saying and speaking. The name to be given can be a word or an expression belonging to a particular language (historical expression), of any grammatical and lexical category, or a word or expression invented by the cognizant subject. Anyway, since language is directed to the You and the name invented is created with the means of expression or a particular language, the name is historical, that is, common and participated. We should understand "a name invented" as a combination entirely new or a new combination formed with traditional procedures or means of expression ${ }^{1}$.

So far the construct created was first conceived of as a sensation (aisthesis ${ }^{2}$ or intuition $^{3}$ ), then the cognizant subject selected something out of it, gave it reality thus delimiting it in some way. With this the construct was made a semantic object. Then the cognizant subject created a class or an essence and applied it to the construct created; then the construct was related in some way to meanings existing either in the individual knowledge of the subject or in the language 4 . The result is that with both the creation of a class or essence and relation, the cognizant subject has an essence to apply it to the semantic object previously created. Now the first task to do is giving the construct made so far a name.

The intellective operation of giving the construct a name has a double function: on the one hand - and this one is the most important - the name given to the construct is used by the cognizant subject to keep it in his conscience, and on the other, it is used by the cognizant subject to offer it to the other speakers. Because of the first function, the cognizant construct

\footnotetext{
${ }^{1}$ Metaphor is a completely new intellective combination, both in its meaning and in the means used.

2 Aristotle, De Anima III, 1, 425a,14, apud Ortega y Gasset 1992a, p. 128.

3 Coseriu 1986a, pp. 27-28.

4 This is usually considered as experience by cognitivists. From my point of view this name is inadequate. Experience denotes sensitive knowledge. Human knowledge is just creation made on the transformation of the sensitive come to humans through their senses.
} 
becomes a means to for the subject to liberate himself from the sensitive he feels himself enchained to5, the circumstance he is in6. A Man, "being in the world", committing himself to "the things constituting the universe" 7 , is not pleased with merely living the things in his circumstance; he will rebel against them fabricating mental constructs with the pretension of dominating them although it is only in his imagination. A human being relates to his circumstance thus transforming it in his imagination. As a cognizant subject he knows with imagining things in his interior thus constituting knowledge, to be kept in his conscience for further use. The way to keep those things imagined is by giving the things conceived of names, that is, signaling them with labels in order to identify them in subsequent occasions. With this at the same time the cognizant subject creates his conscience, his autonomy and freedom. A human subject in this way creates his knowledge now to use it later on, in a dialectics of knowing now and using the things known later on lasting all his life long. With this technique he human subject creates his own means of defense in the world, his conscience, his intelligence, the means valid in his fight against the circumstance.

Because of the second function, offering the thing created and named, the cognizant construct is made common and participated and thus social, since it is offered to others who will try to understand it. The cognizant construct once it is given a name and offered to other speakers, will be accepted or rejected. The act of knowing, saying and speaking thus is made into a means of interchange between the I and the You, thus making themselves historical. A human subject, "being-together-with another one"8, performs himself as a historical subject, a subject who creates his historicity in

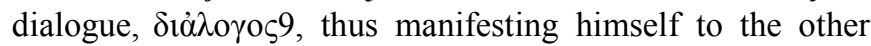
speakers in the act of apprehending, knowing and saying of real things 10. A human subject with the operation of giving

5 As a matter of fact, the subject is connected to the sensitive he lives in. With the act of knowing the human subject imagines he liberates himself from the sensitive thus creating a new connection to it, a mental connection (cf. Ortega y Gasset, 1992a, p. 131.

6 Ortega y Gasset 1994, 190

7 "A Man suffers from something, that is, being [...], existing out of its thought, in a metaphysical exile out of himself, delivered to the essential foreigner which is the Universe. A Man is not res cogitans, but res dramatica. He does not exist because he thinks, but the other way round, he thinks because he exists (Ortega y Gasset, 1987, p. 61) (my translation). This is so because "a Man exists out of himself, in the other things [...]. Living is existing out of oneself, being outdoors, thrown out of oneself, delivered to the sensitive. A Man is essentially a foreigner, emigrated, exiled" (Ortega y Gasset, 1999, p. 66) (my translation).

8 Cf. Coseriu, 1988, p. 43).

9 "Saying, lógos, is nothing but the particular reaction of an individual life. Because of this, in strict terms, there is no argumentation but the one of a subject to another one. [...] Saying, lógos, is extremely real, extremely human conversation,

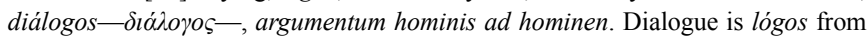
the point of view of the other, the one next to us" (Ortega y Gasset, 1987, p. 16) (my translation).

10 "The human conscience is always a historical conscience and for a human conscience the basic way of manifesting itself is the 'particular language', speaking just like others, that is, as it has been spoken, in accordance with the tradition. In other words: speaking is always speaking a language (not merely making something exterior) because it is speaking and understanding, expressing the construct a name transforms his relating to the world into an act of saying thus manifesting himself to the others as a subject who creates his means of defense, his ideas, his world, his historicity 11. In this sense the intellective operation of giving the construct a name is the one having to do with what it is and makes a human being human, an individual subject going beyond himself by means of his activity of knowing. On the other hand, the act of knowing made into something to be offered to the others, the act of saying, is the motivation for the human subject to manifest himself. A human being when he says something defines himself and constitutes himself in the guarantee of the thing said, because saying is the manifestation of oneself, a living action 12 .

Giving the construct a name, then, makes the individual into social and historical. The act of knowing and saying is the manifestation of an absolute and creative subject on the one hand and on the other a historical and social subject. This has to do with the central problem in linguistics, namely, to explain how some arbitrary sounds without any connection with the things in the world relate with meanings, that is, the connection existing between contents of conscience and the things designate13. A particular linguistic expression reveals the creative spirit of a cognizant, saying and speaking subject and at the same time evinces the common means of expression he uses in order to conceive of and explain the reality he apprehends. The final expression, lógos apophantikós, reveals the original intuition of the speaker and the means he used to create his expressions, his lógos. In the creation of lógos the means used play a decisive role. Lógos is the manifestation of the things conceived of determined with the means used to conceive them of. Lógos thus is a state lived by the cognizant subject, something different from thought and language. Thought is logos in as much as it is performed in words of a language.

Giving the construct a name is a free intellective operation. The cognizant subject selects the words he uses within a wider or narrower range of possibilities. For Coseriu, the historical language, in particular the level he calls the norm of the language, constitutes a series of historical performances offered to the speaker14. The system of the language, on the contrary, is a system of possibilities 15 . The language already performed and constituted in a technique in the tradition of speaking (the norm of the language) in this way is a factor

something in order to let others understand, that is, because the essence of language is given in dialogue" (Eugenio Coseriu, 1988. p. 71) (my translation).

11 "The particular language is the common ground of linguistic historicity of speakers and anything said, it is said in a language, which to a certain extent, manifests itself in the thing said" (Coseriu, 1982, p. 308) (my translation).

12 Cf. Ortega y Gasset, 1992a, p. 253.

13 "The central fact in linguistic activity [...] consists in the eminently spiritual faculty of establishing a functional nexus between signifier and the thing signified" (Coseriu, 1986, pp. 58-59) (my translation).

14 Cf. Coseriu, 1988, p. 197.

$15 \mathrm{Cf}$. "thanks to the system, a system of possibilities, a language is not only what has already been said with its technique, but also what can be said with the same technique: it is not only 'past' and 'present', but it has also a future dimension" (Coseriu, 1986b, p. 326) (my translation). 
conditioning the speech and the thought of speakers, not as something concrete but as a set of forms, contents, rules, procedures, attitudes and beliefs in force in the speech community in which the cognizant subject performs himself, thus contributing to the definition and enlargement of his language as an agent of that degree of historicity.

And this was the problem dealt with by Whorf, a problem he tried to solve with what he called the relativity principle: We are thus introduced to a new principle of relativity, which holds that all observers are not led by the same physical evidence to the same picture of the universe, unless their linguistic backgrounds are similar, or can in some way be calibrated 16. The problem is not about physical evidence, because physical evidence involves the prior solution to the problem: Whorf gave for granted that all "observers" know that physical evidence in the same way. It is not reality the thing existing prior to the apprehension by the cognizant subject, but it is the cognizant subject the one who creates reality. Those "observers" do not observe reality, but create it laboriously and precariously. For Whorf, the problem was in particular languages not in the act of knowing, something implicit in language17:

Users of markedly different grammars are pointed by their grammars toward different types of observations and different evaluations of externally similar acts of observation, and hence are not equivalent as observers but must arrive at somewhat different views of the world 18 .

Languages are nothing but historical objects created by speakers. They do not have concrete existence. Languages exist in the minds of speakers as formal and semantic mode of speaking 19, that is, a model existing in their conscience. Speakers try to reproduce the modes of knowing, saying and speaking but in a creative manner. The problem of the relation language and thought consists in explaining the connection with some arbitrary signs and thought. A human subject speaks because he knows, and because he knows he re-structures the things surrounding him, that is, he has something to say, and because he knows and says, he speaks. He creates his saying using traditional and historical forms not only for saying and thus speaking but for knowing as well. And this constitutes the double reality of the cognizant, saying and speaking subject. A human being is an absolute, creative and free subject but at the same time is a historical and contingent subject, a subject living and participating in a speech community. The problem consists in delimiting how far those forms are traditional and how far they are creative and individual. Or in other words: it is about determining what extent the thought of an individual subject is individual or historical, or what extent the individual subject uses models in

16 Whorf, 1956, p. 214.

17 Some linguists, especially those whose native language does not distinguish the reality involved in the word 'language' (language, a language) will accept this fact as if it was reality itself. Something is the reality of language and something else the reality denoted in a word of a particular language.

18 Whorf, 1956, p. 221.

19 Coseriu, 1985, p. 48. force in his tradition or creates them.

But Whorf, even when he does not give the exact solution to the problem, can see the elements constituting it. It is language that determines lógos, not grammars, as he said. Lógos is previous to thought.

Giving the construct a name is the foundational problem in linguistics in a double sense: it is the expression of the act of knowing, on the one hand and on the other, it is the revelation of the historical reality in which the cognizant, saying and speaking subject performs himself. The cognizant subject defines himself before the thing said thus making himself into a creative subject, someone in fight against his circumstance. In this sense linguistics must explain the connection existing in the things being said, lektón20, and the very act of knowing.

Giving the construct a name is the revelation of the historical reality the cognizant, saying and speaking subject performs. This reality makes linguistics have the assignment of explaining the connection of the creative subject and his work, a necessarily historical connection. Both aspects constitute lógos apophantikós, the revelation of the cognizant reality and the historical reality thus prompting the saying subject to say something.

The so-called problem of arbitrariness of signs is nothing but the formulation of the problem of knowledge in linguistic terms. Words mean because they are accepted by the speakers of a

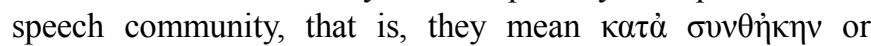
secundum placitum, ad placitum, that is, they are unmotivated and mean because the speech community considers them in the way stated 21 . Eventually language exists as the creation meanings 22 , not to reflect reality, a mere circumstance affecting language. The solution to this problem is to be given at the historical level. We speak and conceive of reality as it is spoken and conceived of in a particular speech community. The individual subject creates his forms of conceiving of reality, saying and speaking in accordance with models of knowing, saying and speaking in force in his historicity, that is, in his speech community or particular language 23 . From this perspective, the cognizant, saying and speaking subject reveals himself as the heir of a tradition in the way of knowing, thinking, saying and speaking. Since language is transcendent, that is, it aims at achieving something and since the speaking subject is together-with-the other speakers, words are purposefully and historically motivated.

A cognizant subject in order to give a name to his cognizant constructs, that is, in order to create his contents of conscience, turns his eyes to the traditional and historical because of three reasons:

20 In lógos you can see the following aspects, lógos, the state lived by the speaking, saying and knowing subject in his interior; lektón, the things that can be said; logos semantikós, logos inter-individual and common, and lógos apophantikós, lógos determined by the concepts of existence/non-existence and truth/non-truth. Both logos semantikós and logos apophantikós can be executed at the thee levels of linguistic determination (cf. Martínez del Castillo, 2009).

21 Cf. Coseriu, 1977, pp. 3-61.

22 Coseriu, 1985, p. 46.

23 Cf. Coseriu, 1992, 254-255. 
- Because he is creator of his historicity for others24

- Because he is absolute, that is, creator of his forms of knowing and speaking in accordance with prior models 25

- And because he creates his own tradition in knowing, saying and speaking 26 .

A human being whenever he apprehends and knows something he assimilates what he has known and keeps it in his conscience for subsequent use and manipulation as contents of conscience. In this way the thing learnt and repeated thousands of times after, is eventually constituted in the individual way of apprehending things, thus forming his individual tradition. Since this way of apprehending things is completely or partially historical, the thought of the individual subject reflects the historical reality in which a particular subject performs himself as a human.

Giving the construct a name in the act of knowing has two main effects: on the one side it means the transformation of the nature of the construct being made, and on the other, it makes the cognizant construct objective. The cognizant construct, aisthesis, initially with a sensitive nature, then made abstract, virtual and objective, now with giving it a name is made into something capable of being stored in the conscience of individuals, not sensitively but in an abstract, mental way. If the cognizant subject, as it was explained in another article, is cold, he feels something unfavorable and when he keeps it in his conscience he will associate that sensitive feeling to something abstract invented by him. Because of this the thing he keeps in his conscience is something mental, something delimited and made contents of his conscience.

But the cognizant construct the subject keeps in his conscience, by the mere fact of being kept in his conscience through giving it a name and earlier since it had been selected and delimited, has many other cognizant shades of meaning with it created on the spot when all these intellective operations are applied to. A cognizant construct by the mere fact of being selected, delimited, assigned to a class or essence and given a name acquires with it what we can conceptually call its contraries. So if I keep in my conscience a sensation of cold or hunger I keep its contraries with it. The reason for this is that I have delimited the sensation of cold or hunger with the only means I have to delimit something sensitively, by imagining that the sensation affecting me does not exist. That is, I am cold or hungry and wish I were not cold or hungry. With this the sensitive construct, which was formerly something sensitive and thus something formless, is made into something abstract and definite, an idea, a semantic construct thus constituting the conscience of the subject creating it. In this way it will be used to offer it to others, an idea bearing in itself its own delimitation and many more shades of meaning

24 For Coseriu, "a speaker is the creator of language 'for other speakers"”, (1988, p 57).

25 Cf. Coseriu, 1988, p. 71.

26 Some authors in accordance with the proposal by Bernhard Bloch accept the name "idiolect" for the language of the individual. A language is a language at least for two subjects (cf. Coseriu, 1992, p. 54) (my translation). associated with it, no longer a sensation.

The fact that some cognizant constructs are made into semantic constructs can be verified in the vocabulary of a historical language. In this way we can see that some facts appear in contraries but they are not perfect contraries. We usually say that young opposes old, that is, they keep a relationship of signification at both ends of a polar relationship thus establishing an antonymic relationships of signification. This explanation from the intellective point of view cannot be true. These contraries are not perfect but elaborations placed at both ends of an invented linear relationship of signification apart from the fact of something being young or old. Young does not oppose old but both words constitute two coinages to a certain extent opposing each other. Young opposes non-young and old, non-old. Between young and old there are many relationships of signification, sometimes lexicalized in a particular language, and sometimes non-lexicalized. Hence that sometimes lexicographers speak of empty categories or holes in the vocabulary. Young bears with it shades of meaning lacking in old and the other way round. Young, for example, is only to be applied of 'person' or 'living' but old is to be applied of both 'living' and 'and non-living'. In this way, the cognizant construct when it is selected, delimited, assigned to an essence and given a name is made into a semantic construct, an idea representing a series of shades of meaning, in which the most important and fundamental is the first sensation having given birth to knowledge.

And with this, once again, we eventually came to the most fundamental problem in linguistics: the problem of the value of signs. Linguistic signs do not constitute real things, nor does the initial sensation having prompted them to be. Every one of them is but a set of sensations and additions to these sensations thus making the language a-temporal, a-circumstantial and virtual, something very different from the thing designate.

On the other hand, the cognizant construct which started as something formless, without any delimitation at all, something the reality of which was merely something affecting the cognizant subject, is now conceived of as something separated from the cognizant subject. At the beginning it was merely felt, now it is conceived of as something existing in itself and apart from the subject creating it and conceiving of it. The cognizant construct, starting with the initial intuition or aisthesis, sensitive, individual and previously unknown, is made into an objective construct, an idea, a word, a semantic construct to be used by its creator, the cognizant saying and speaking subject, as a reference for further uses in his relation to the world, that is, reality. This construct is no longer sensitive but abstract and "essential", that is, virtual, a construct with no sensitive performance in the world constituting the circumstance in accordance with it was created, but something the cognizant subject tries to perform in the world. In this way the cognizant subject separates himself from the thing known thus making it real. The cognizant subject separates the cold or hunger he feels from his own self. Now the cognizant subject is ready to 
consider himself as someone affected by cold or hunger, two things that now, by virtue of the intellective operations in the act of knowing especially through giving the construct a name, can coexist in his mind as different and with no connection with each other, although it is difficult for him to get rid of that thing called cold or hunger. But we have to say that these two things are not two but four:

- The cognizant subject or the "I",

- The object known (hunger or cold),

- The reality the cognizant subject designates with the object known (the reality of being cold or feeling hunger),

- The reality with which the cognizant subject designates the object known or the world (that is, language).

Giving the construct a name as a consequence is necessarily historical, either in its totality, in its forms and extent, or in its purposes since the semantic construct is directed to others. In this sense, the particular language or the tradition in knowing, saying and speaking is always present in the thought of the cognizant subject. This historical condition of thinking and saying is something we can clearly verify comparing languages. For example, the reality denoted with the English word wall encompasses the reality of the set of Spanish words, pared, muro, muralla, tapia, and tabique. Every one of these five Spanish words denotes a different reality, they all relating to the English word wall27.

\section{Determination}

The last intellective operation in the act of speaking, saying and knowing is determination. It consists in orientating the construct created to the real. So far we have said that the cognizant construct is made by selecting something out of the thing we apprehend, delimiting it in some way, attributing it reality thus making it a semantic object, creating a class or essence in order to attribute it to the semantic construct created so far, relating to other things already known28, and giving it a name to keep it in our conscience and offer it to the other speakers. The construct created, transformed from the sensitive into abstract thus making it objective, virtual and social is now a semantic construct designating not things in the world but essences. Thanks to these essences, made social because they are common and participated in the speech community, speakers can understand one another. Thanks to this as well the linguistic expression is ambiguous: one thing is the thing said, something else is the thing meant, and something else the thing understood. If the act of apprehending and conceiving of things on the one hand, and understanding on the other, is individual by definition, the interchange between the speaker and the listener is possible but with the limitation said: we speak in essences and apply the essences created to the things we apprehend. What we

27 You can see other examples in Martínez del Castillo, 2004, pp. 140-142.

28 The first four intellective operations constituted the process of abstraction in the creation of meanings. apprehend on the one hand, the thing we say of on the other, and the things we refer to on the other, constitute objects with different nature incompatible with each other. As a consequence, any act of knowing and understanding is creative because, first, essences do not exist, we have invented them; second, what we understand constitutes something different with different nature as the essences; and third, we apply the essences to the formless continuum of what we apprehend, the sensitive. We have to tackle with two things, the essences (concepts or categories) on the one hand and on the other the continuum of reality. The essences, concepts or categories are abstract, what we perceive is concrete and formless. In this the mystery of knowing lies: in transforming what we perceive, the sensitive and concrete, into abstract and then make it real.

The speaker or the cognizant, saying and speaking subject creates essences to be interpreted by the listener. The speaker starts with a sensation (an initial intuition or aisthesis) to create contents of conscience through historical means in force in the historical speech community. The listener, on the contrary, starts with the historical means as his initial apprehension of the thing said, and then he interprets it thus creating an aisthesis of his own mentally and eventually contents of conscience. They constitute two different processes, both aiming at the same purpose, the contents of conscience aiming at the real and interpreting the means of expression in terms of the real.

The means of connection between the speaker and the listener is abstract, virtual and essential, the thing to be virtually applied to many possible items or objects created or to be created, something impossible to be identified with anything real. In this sense speech is good for anything. It is potential and virtual and can be applied of real things 29 . Thinking in this way reveals as something different from speaking and different from saying. Thinking creates objects in the world conceived of as instruments to manipulate the things constituting the circumstance the cognizant, saying and speaking subject is in, but these instruments are not real. The essences of thought are good within a particular order or cosmos, a world not just the world constituting the circumstance the subject is in but a fantastic world.

The problem arises then when the cognizant subject tries to say something, that is, when he wants to go out of his mental world and needs to get into contact with the things constituting his circumstance, the "other thing" 30 , thus rearranging it. The cognizant subject needs orientating his mental constructs to the things in the world to make them real. In order to achieve this he uses a series of intellective and cognizant operations manifesting themselves very clearly in a particular language to be grouped under the heading of determination.

\footnotetext{
29 Speaking, the same as with saying, is language and language is a-circumstantial (cf. Coseriu.1982, p. 290).

30 A human being is nothing but the "active coexistence of me or I with the circumstance or world [...]. I call this co-existing 'my life' [...]. It is me who exists $[\ldots]$ but this (my) existing and thus, I, consists in coexisting with the other, with the world" (Ortega y Gasset, 1992b, pp. 46-47) (my translation).
} 
In particular languages there exist the so-called determiners, linguistic elements with the function of "determining". But these are not the only elements being used to perform this function. As a matter of fact there are some languages with no determiners but the function of determination is performed as well through gestures, context and other procedures. The cognizant, saying and speaking subject performs the speech act with all its being. Human subjects can manage to use all types of means, either linguistic or non-linguistic, to express his meaningful intentional purpose. The final step in the execution or their meaningful intentional purpose is orientating his constructs to things in the world, thus making them real.

Determination is a system of intellective operations performed by the saying subject just because he has something to say. He says because he is able to know and compromise before the things constituting the circumstance he is in. In this way the subject at the same time manifests himself. Determination is the series of intellective operations necessary to know and say something. If there is something said, then there must be determination. Saying is nothing but revealing the interior state the subject lives and wants to reveal to other speakers. What happens in his interior is something mental, abstract, known only by its author. When he tries to say what he lives in words he must orientate it to the real. His interior state reveals the re-structuring he has made on things thus defending that re-structuring made and constituting himself in the guarantee of it. In this sense the individual cognizant, saying and speaking subject compromises. The saying subject creates things, puts an order on them, systematizes and establishes an order on them. This action would be impossible if the subject did not put aside the essences he has created and made them things in the world of the real. Determination in this way is mental and intellective. Without it there would not exist the interchange between the I and the You, that is, there would not exist the speech act, that is, language and even the human subject. In a world of knowledge without determination a man would not be a "being in the world", a "being there"31, "someone in his circumstance" 32.

As I said above, determination consists in orientating the essences created to things in the world thus creating reality and the real. If at the beginning we created constructs with no reference to the things in the world, that is, we created something mental with no concrete existence nor any possibility of having existence, now when we determine those mental constructs we create reality, that is, things just as they are in the real world. With this, that is, with determination human thought changes. Up to the intellective operations of creation of a class or an essence and relation (the process of abstraction in the creation of meanings), human knowledge and thus human thought is a process of creation ex nihilo, purposefully determined, with no external causes. From determination, since the essences once given a name are

31 Cf. Heidegger, 2002, p. 62.

32 Cf. Ortega y Gasset, 1992b, pp. 46-47. determined, human knowledge and thought starts with a new process in which the things created are considered to exist in themselves not in the mind but in the world made into reality because of determination. This tree is no longer a possible member of the class "tree" but the magnolia I can see from my window, a tree with particular individual characteristics or an essence, something I must verify if I want to know of it. It is not a class or a member of a class but the tree I can see, the tree I apprehend with my senses. There may be many other magnolias but they do not constitute the object of my knowledge and my thought. It is a singular individual item of magnolia, a real one since I can verify it and apprehend through my senses.

Since we started with selection, abstraction consisted in extracting something out of the sensitive and concrete thus creating out of it. But from determination on, the human subject looks for characteristics in the objects created made into real, thus starting with a new process of abstraction, the one consisting in creating new essences and immediately verifying if they are given in the real objects created. As a result, we can see entities in real things, different and independent from the subject who created them, that is, we can see them as "things". From this moment on, the cognizant subject "lets things speak to him" 33 thus creating language, a linguistic world and a type of knowledge he will consider as something "objective". And from this moment on, the cognizant subject can use analogy34 thus creating synthetic $a$ priori statements 35 to interpret real things.

Language as cognizant activity 36 is born in the very act of knowing by the human subject, in the very foundation for a human being to be human, a human being able to ask for being and interpret it 37 . It is important to realize the name of this intellective operation, determination and determining. Determination and determining is nothing but considering something in terms of something else, that is, orientating something towards something. That is, the classes or essences are to be interpreted in terms of something contrary to the nature of essences, the concrete or experience. Human knowledge thus is unique. It puts together the contraries in one act. It is the act of making reality present 38 .

\section{Conclusion}

Human knowledge, thus, is the synthesis of sensation and

\footnotetext{
33 Cf. Heidegger, 1970, p. 14.

34 For Ortega y Gasset, analogy, the foundation in the mode of thinking introduced by Descartes, considering things not as things but as correlates, constitutes the base in the interest for science and a procedure unavoidable in human knowledge (cf. 1992a, pp. 148 \& ff.).

${ }^{35}$ Statements formed out of sensation (experience) and intellect (reason) through imagination (something invented by the speaker) based on analogy, cf. Kant, 2004, pp. 7-52.

36 Cf. Eugenio Coseriu, 1985, p. 42

37 Cf. Eugenio Coseriu, 1985, p. 33

38 "Language, cognizant activity, is the union of reason and thing $[\ldots]$, $v$ ỏ $\eta \sigma \imath \varsigma \tau \tilde{\omega} v \dot{\alpha} \delta$ \& $\varepsilon \rho \dot{\varepsilon} \tau \tilde{\omega} v$, apprehensio indivisibilium" (Coseriu, 1985, p. 55) (my translation).
} 
intellect. It starts with sensation (intuition, aísthesis) and ends in experience (verification of the objects previously created by means of imagination), that is, sensation. In between the beginning and end it is intellect, what the human subject adds on his part. So human knowledge is made up of that peculiar way of approaching reality consisting in the use of synthetic a priori statements, in which sensation, imagination, intellect and language are involved.

\section{References}

[1] Coseriu, «L' arbitraire du signe», in Tradición y novedad en la ciencia del lenguaje: estudios de historia de la lingüística, Madrid: Gredos, 1977 [1971].

[2] Coseriu, E., Principios de semántica estructural, Madrid: Gredos, 1981 (1977).

[3] Coseriu, E., Teoría del lenguaje y lingüística general: cinco estudios, Madrid, Editorial Gredos, 1982 [1962].

[4] Coseriu, E. El hombre y su lenguaje, estudios de teoría y metodología lingüística, Madrid: Gredos, 1985 [1977].

[5] Coseriu, E. Introducción a la lingüística, Madrid: Gredos, 1986a [1951].

[6] Coseriu, E. Lecciones de lingüística general, Madrid: Gredos, $1986 b$ [1973].

[7] Coseriu, E., Gramática, semántica, universales. Estudios de gramática funcional, Madrid: Gredos, 1987 [1978].

[8] Coseriu, E., Sincronía, diacronía, e historia: el problema del cambio lingüístico, Madrid: Gredos, 1988 [1957].

[9] Coseriu, E., Competencia lingüística: elementos de la teoría del hablar, Madrid, Editorial Gredos, 1992 [1988].

[10] Coseriu, E. y Ó. Loureda: Lenguaje y discurso, Pamplona, Eunsa, 2006.

[11] Coseriu, E. Lingüística del texto. Introducción a la hermenéutica del sentido, Arco/Libros, 2007.

[12] Di Cesare, D., Wilhelm von Humboldt y el estudio filosófico de las lenguas, trad. Ana Agud, Anthropos, 1999.

[13] Heidegger, Martin, Carta sobre el humanismo, Madrid: Destino, 1970.

[14] Heidegger, Martin, El ser y el tiempo, RBA Editores, 2002 [1944].

[15] Humboldt, W., «Ueber die Verschiedenheit des menschlichen Sprachbaues und ihren Einfluss auf die geistige Entwickelung des Menschengesschlechts» trad. Ana Agud: Sobre la diversidad de la estructura del lenguaje humano y su influencia sobre el desarrollo espiritual de la humanidad, Madrid, Anthropos y Ministerio de Educación y Ciencia, (1990) [1836].

[16] Kant, Immanuel, Crítica de la razón pura, RBA, 2004.

[17] Luque Durán, Juan de Dios, Aspectos universales y particulares del léxico de las lenguas del mundo. Granada: Granada Lingvistica, 2001.

[18] Martínez del Castillo, Jesús, La intelección, el significado, los adjetivos, Universidad de Almería, 1999.
[19] Martínez del Castillo, Jesús, Significado y conocimiento: la estructura de significación de los adjetivos subjetivos, Granada:

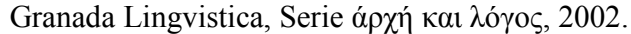

[20] Martínez del Castillo, Jesús, La lingüística del decir. El logos semántico y el logos apofántico, Granada: Granada Lingvistica,

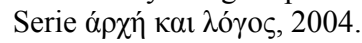

[21] Martínez del Castillo, Jesús, «Hablar, decir y conocer: el acto lingüístico», Oralia, 11 (2008): 375-97.

[22] Martínez del Castillo, Jesús: «El logos semántico y el logos apofántico» Enérgeia I, Online-Zeitschrift für Sprachwissenchaft, Sprachphilosophie und Sprachwissenschaftsgeschichte. 2009: 50-80.

[23] Martínez del Castillo, Jesús: Las relaciones lenguaje-pensamiento o el problema del logos, Madrid: Bilbioteca Nueva, 2010.

[24] Martínez del Castillo, Jesús, Sobre las categorias, Buenos Aires, Deauno.com, 2011.

[25] Martínez del Castillo, Jesús, ed. Eugenio Coseriu (1921-2002) en los comienzos del siglo XXI, 2 vols. in Analecta Malacitana, Anejos/86, 2012.

[26] Martínez del Castillo, Jesús: Psicología, lenguaje y libertad, in Analecta Malacitana, Anejos/89, Universidad de Málaga, 2012.

[27] Martínez del Castillo, Jesús: Modes of Thinking, Language and Linguistics, in Analecta Malacitana, Anejos/94, 2013, Universidad de Málaga.

[28] Ortega y Gasset, José, El tema de nuestro tiempo, Alianza Editorial, 1987 [1981].

[29] Ortega y Gasset, José, ¿Qué es filosofía?, Alianza Editorial, 1994 [1957].

[30] Ortega y Gasset, José, Unas lecciones de metafísica, Alianza Editorial, 1999 [1966].

[31] Ortega y Gasset, José, La idea de principio en Leibniz, Alianza Editorial, 1992a [1958].

[32] Ortega y Gasset, José, ¿Qué es conocimiento?, Alianza Editorial, 1992b [1984].

[33] Ortega y Gasset, José, Sobre la razón histórica, Alianza Editorial, 1996 [1979].

[34] Ortega y Gasset, José, «El decir de la gente: la lengua. Hacia una nueva lingüística» in El hombre y la gente, Alianza Editorial, 2001 [1957].

[35] Ortega y Gasset, José, «El decir de la gente: las 'opiniones públicas', las 'vigencias sociales"'. El poder público» in El hombre y la gente, Alianza Editorial, 2001 [1957].

[36] Ortega y Gasset, José, "En torno al coloquio de Darmstadt", in Meditación de la técnica y otros ensayos de ciencia y filosofía, 2002 [1982]: 192-233.

[37] Ortega y Gasset, José, “Apuntes para un comentario al banquete de Platón“, Obras completas, IX, Taurus, 2009: 729-758.

[38] Edward Sapir, El lenguaje, introducción al estudio del habla, México: Fondo de Cultura Económica,

[39] Whorf, Benjamin Lee, Language, Thought and Reality, J. B. Carrol, (ed.) Cambridge, Mass, The MIT Press. 